\title{
Hypopituitarism: A Very Rare Cause of Dilated Cardiomyopathy in a Child
}

Mandal A ${ }^{1}$, Singh A $^{2}$

\begin{abstract}
Dilated cardiomyopathy (DCMP), the leading type of cardiomyopathy in children, can be either a primary disease or secondary to a host of pathologies. Endocrine diseases are an extremely rare cause of DCMP in children. Hypopituitarism (congenital or acquired), a rare condition in children, may present in a variety of phenotypes depending on the hormonal deficiency (partial vs. pan hypopituitarism) and associated developmental defects. We describe a 10 year old boy with short stature, severely retarded bone age and congestive cardiac failure (CCF). He was diagnosed to have DCMP with hypopituitarism. Review of literature reveal possible mechanisms of DCMP and CCF in hypopituitarism and probably also indicate favorable response to hormonal replacement therapy.
\end{abstract}

Key words: Congestive cardiac failure, Hypoglycaemia, pericardial effusion, Short stature

\section{Introduction}

$\mathrm{H}^{2}$ ypopituitarism is defined as absence or reduction in function of two or more hormones produced by the pituitary gland ${ }^{1}$. It affects 1 in 4000 to 1 in 10,000 live births, with incidence increasing with age $^{2}$. Congenital hypopituitarism may present in a variety of phenotypes depending on the hormonal deficiency (partial vs. pan hypopituitarism) and associated developmental defects ${ }^{1,2}$. Dilated cardiomyopathy (DCMP) is the leading cause of cardiomyopathy in both adults and children with a poor long term prognosis ${ }^{3}$. DCMP is a rare condition with an incidence of $0.56-1.24 / 100,000$ children per year; boys and infants being affected more commonly ${ }^{3,4}$. It can be either a primary condition or secondary to a host of secondary causes with the commonest recognizable cause being myocarditis ${ }^{3}$. Endocrinologic causes of DCMP are extremely rare in children; mostly associated with thyroid dysfunction ${ }^{5}$. Among the adults also, metabolic causes constituted only $1.5 \%$ of cases, again, mostly due to thyroid disorders ${ }^{6}$. We report a 10 years old boy with hypopituitarism and DCMP presenting with cardiac failure.

\section{The Case}

A-10-year-old boy presented with complaints of insidious onset, gradually progressive dyspnoea and orthopnoea for six months.
${ }^{1}$ Dr. Anirban Mandal, Attending Consultant, Department of Paediatrics, Sitaram Bhartia Instiute of Science and Research, New Delhi, India, ${ }^{2}$ Dr. Amitabh Singh, Assistant Professor, Department of Paediatrics, VMMC and Safdarjung Hospital, New Delhi, India [ORCID iD: http://orcid.org/0000-0002-4440-5339].

\section{Address for correspondence}

Anirban Mandal

E-mail: anirban.nrs@gmail.com

\section{How to cite}

Mandal A, Singh A. Hypopituitarism: A Very Rare Cause of Dilated Cardiomyopathy in a Child. J Nepal Paediatr Soc 2017;37(2):197200.

doi:http://dx.doi.org/10.3126/jnps.v37i2.17278

This work is licensed under a Creative Commons Attribution 3.0 License. 
There was also history of abdominal distension, pedal oedema, easy fatigability, constipation, noisy breathing and somnolence. The child was $1^{\text {st }}$ born to a nonconsanguineously married couple. He was born at term by normal vaginal delivery at home with apparently normal birth weight. There was history of delayed cry at birth requiring stimulation. He had feeding difficulty and failure to thrive since beginning and also had global developmental delay with cognition affected more than the motor and language domains. There was no history of palpitation, black out, jaundice, decreased urine output, seizure, altered sensorium, bleeding from any site or requirement for blood transfusion. There were four younger apparently normal male and female siblings and no history of abortion in the mother or early infantile death in the family. There was no similar history in the family. He consumed $1100 \mathrm{kcal}$ and $19 \mathrm{gm}$ protein per day.

On examination, the child was lethargic with cold peripheries, heart rate $100 / \mathrm{min}$, all peripheral pulses well palpable, capillary filling time $<3$ seconds, BP 116/ $70 \mathrm{mmHg}$. He had marked respiratory distress with tachypnoea (respiratory rate $36 / \mathrm{min}$ ), chest retractions and intermittent stridor. There was hypoxemia evident by central cyanosis and Spo2 of $80 \%$ in room air. Anthropometry revealed short stature (height $75 \mathrm{~cm},<-3$ SD), with upper: lower segment ratio 42: 33 , underweight (10 kg, <-3 SD), and microcephaly (head circumference $46 \mathrm{~cm},<-3 \mathrm{SD})$. General physical examination revealed, moderate pallor, pitting pedal oedema, dry scaly skin, pot belly, frontal bossing, saddle nose, macro-glossia, low set ears, sparse hair and anterior fontanel was still open (Figure 1a). There was evidence of delayed dentition as well. His sexual maturity was at Tanner's stage 1. Systemic examination was remarkable with presence of ascites, hepatomegaly, and crepitation on auscultation of both lungs and a Grade- 3 ejection systolic murmur without any S3 gallop.

Investigations revealed bone age <1 year (Figure 1b), microcytic, hypochromic anaemia, markedly elevated serum alkaline phosphatase, and recurrent episodes of asymptomatic hypoglycaemia (Table 1). Chest $x$-ray showed massive cardiomegaly (Figure 1c) and echocardiography confirmed dilated ventricles with tricuspid and mitral regurgitation, biventricular dysfunction (ejection fraction 45\%) and pericardial effusion ( $8 \mathrm{~mm}$ ) but no evidence of tamponade. He was started on moist $\mathrm{O} 2$ inhalation, diuretic (Frusemide) and Digoxin with improvement in symptoms. Further investigations were suggestive of hypopituitarism with central hypothyroidism, hypoprolactinaemia, hypocortisolism (Table 1) and growth hormone $(\mathrm{GH})$ deficiency $(\mathrm{GH}$ on $\mathrm{GH}$ stimulation test: at 0 hour- undetectable, at 30 minutes-undetectable, at 60 mins$0.1 \mathrm{ng} / \mathrm{ml}$, at $120 \mathrm{mins}-0.2 \mathrm{ng} / \mathrm{ml}$ ). Water deprivation test could not be done in view of the critical condition of the patient and diuretic therapy.

Thyroxine (at a dose of $5 \mathrm{mcg} / \mathrm{kg} / \mathrm{day}$ ), growth hormone (Recombinant growth hormone @ $0.25 \mathrm{IU} / \mathrm{Kg} /$ week) and hydrocortisone (at a dose of $10 \mathrm{mg} / \mathrm{m}^{2} /$ day) supplementation was started. MRI (Magnetic resonance imaging) of brain could not be done in view of the child's poor general condition and facilities for genetic studies for known mutations of hypopituitarism were not available at our centre. With further symptomatic improvement, the parents took the child home against medical advice and he was lost to follow up.

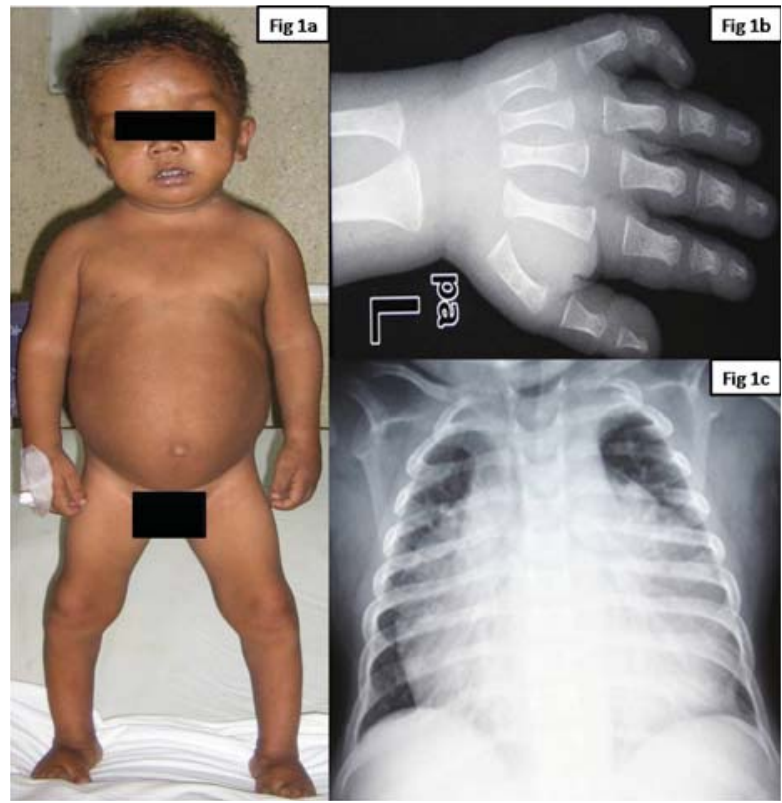

Fig 1a: 10 year old boy with short stature, microcephaly, dry scaly skin, pot belly, frontal bossing, saddle nose, macro-glossia, low set ears and sparse hair;

Fig 1b: X-ray of left wrist and hand showing absence of ossification centres of the carpal bones and distal radial epiphysis;

Fig 1c: Chest $x$-ray showing huge cardiomegaly with water bottle shaped cardiac shadow suggestive of pericardial effusion

\section{Discussion}

We present a paediatric case of hypopituitarism leading to DCMP and cardiac failure. DCMP secondary to hypopituitarism leading to cardiac failure has been reported both in adults ${ }^{7}$ and newborn ${ }^{8}$. But, to the best of our knowledge, no such case has reported in the pediatric age group in the English literature before.

Cardiomyopathy associated with hypopituitarism may be attributed to $\mathrm{GH}^{9}$, glucocorticoid ${ }^{10}$ and thyroid ${ }^{11}$ 
Table 1: Investigation reports of the case

\begin{tabular}{|c|c|c|c|}
\hline Investigation & Result & Investigation & Result \\
\hline Haemoglobin (gm/dl) & 7.3 & Total protein (gm/dl) & 4.9 \\
\hline $\begin{array}{l}\text { Total leukocyte count (/ } \\
\left.\mathrm{mm}^{3}\right)\end{array}$ & 14600 & Albumin (gm/dl) & 2.5 \\
\hline $\begin{array}{l}\text { Differential leukocyte } \\
\text { count }\end{array}$ & $\begin{array}{c}\text { Neutrophil } 76 \% \text {, Lymphocyte } 19 \% \text {, } \\
\text { Monocyte } 4 \% \text {, Eosinophil } 1 \%\end{array}$ & $\begin{array}{l}\text { Serum glutamic-oxaloacetic } \\
\text { transaminase (SGOT) (U/L) }\end{array}$ & 88 \\
\hline Platelet count & $2.9 \mathrm{lakh} / \mathrm{mm}^{3}$ & $\begin{array}{c}\text { Serum glutamic pyruvic } \\
\text { transaminase (SGPT) (U/L) }\end{array}$ & 93 \\
\hline Peripheral smear & $\begin{array}{c}\text { Microcytic, hypochromic red } \\
\text { blood cells with marked aniso- } \\
\text { poikilocytosis; no abnormal cells/ } \\
\text { blasts }\end{array}$ & Alkaline phosphatase (U/L) & 1080 \\
\hline Sodium (mEq/L) & 131 & $\begin{array}{l}\text { TSH (Thyroid stimulating } \\
\text { hormone) }(\mu \mathrm{lU} / \mathrm{ml})\end{array}$ & $\begin{array}{c}0.24 \\
\text { (normal } 0.37-6)\end{array}$ \\
\hline Potassium (mEq/L) & 5.0 & $\begin{array}{l}\text { FT4 (Free Tetra- } \\
\text { iodothyronin) (ng/dl) }\end{array}$ & 0.69 (normal 0.8-2) \\
\hline Urea (mg/dl) & 28 & $\begin{array}{l}\text { FT3 (Free Tri-iodothyronin) } \\
\text { (pg/ml) }\end{array}$ & 0.49 (normal 3-5.9 \\
\hline Creatinine $(\mathrm{mg} / \mathrm{dl})$ & 0.6 & Prolactin (ng/ml) & 0.05 (normal 0.9-12.9) \\
\hline Uric acid (mg/dl) & 5.6 & Early morning cortisol $(\mu \mathrm{g} / \mathrm{dl})$ & 1 (normal 2.4-22.9) \\
\hline Calcium (mg/dl) & 8.9 & Serum testosterone (ng/dl) & 0.2 (normal 0-20) \\
\hline Phosphate (mg/dl) & 4.6 & $\begin{array}{l}\text { Leutinising hormone }(\mathrm{LH}) \\
\qquad(\mathrm{mlU} / \mathrm{ml})\end{array}$ & 0.1 (normal $0-0.5$ ) \\
\hline $\begin{array}{l}\text { Total bilirubin/ } \\
\text { conjugated (gm/dl) }\end{array}$ & $0.5 / 0.1$ & $\begin{array}{l}\text { Follical stimulating hormone } \\
\qquad(\mathrm{FSH})(\mathrm{mlU} / \mathrm{ml})\end{array}$ & 0.3 (normal $0.3-4.6$ ) \\
\hline
\end{tabular}

deficiency. GH is a physiological regulator of myocardial growth and performance. Cardiac growth and function are impaired in children with congenital GH deficiency. In these cases, administration of $\mathrm{GH}$ leads to increase in wall thickness and normalization of cardiac performance which also reverses upon stopping the treatment ${ }^{12}$. Thyroid hormones, principally T3 (Tri-iodothyronine), exerts its actions on the cardiovascular system by its genomic modification over cardiac myocytes and extranuclear nongenomic effects on both myocyte and on the systemic vasculature. The mechanisms through which hypothyroidism can lead to heart failure includes: bradycardia, impaired systolic function, impaired left ventricular diastolic filling, increased systemic vascular resistance, diastolic hypertension, increased arterial stiffness and endothelial dysfunction. Both experimental and clinical studies have demonstrated thyroid hormone supplementation to reduce myocyte apoptosis and consequently improve cardiovascular performance and ventricular remodeling ${ }^{13}$.

The pituitary dysfunction in our case seemed to be congenital, as the child was symptomatic since the very beginning with poor growth along with severely retarded bone maturation, presence of micro phallus and absence of any history suggestive of secondary causes of hypopituitarism (e.g. head trauma, surgery, neuro-infection, cranial radiation, etc. $)^{1,2}$. We could not perform a water deprivation test to assess antidiuretic hormone $(\mathrm{ADH})$ function; therefore, it remained unclear, whether it was a case of pan hypopituitarism or partial hypopituitarism. Though, historically, there was no polyuria suggesting ADH deficiency. Genetic testing could not be performed in our case to find the known mutations associated with hypopituitarism; however, the child also did not have any features (such as midline defects, visual disturbances, etc) to suggest a genetic defect. We started $\mathrm{GH}$, corticosteroid and thyroid replacement together as it was found to be safe and effective in both adult and neonate previously 7,8 but unfortunately, we could not follow the child to demonstrate their long term effect on the cardiovascular function.

\section{Conclusion}

We appreciate that association of hypopituitarism with DCMP in this case may not necessarily imply causal association. But the available literature does suggest that hypopituitarism may present with DCMP and respond favourably to a combination of hormonal replacement therapy along with standard therapy for CCF. 


\section{References}

1. Geffner ME. Hypopituitarism in childhood. Cancer Control 2002;9(4):212-22. DOI: 10.1530/EJE-13-0280.

2. Pierce M, Madison L. Evaluation and Initial Management of Hypopituitarism. Pediatr Rev 2016;37(9):370-6. DOI: 10.1542/pir.2015-0081.

3. Hsu DT, Canter CE. Dilated cardiomyopathy and heart failure in children. Heart Fail Clin 2010;6(4):415-32, vii. DOI: 10.1016/j.hfc.2010.05.003.

4. Towbin JA, Lowe AM, Colan SD, Sleeper LA, Orav EJ, Clunie S, et al. Incidence, causes, and outcomes of dilated cardiomyopathy in children. JAMA 2006;296(15):1867-76. DOI: 10.1001/ jama.296.15.1867.

5. Underland LJ, Villeda GA, Pal A, Lam L. A Case of Thyroid Storm Associated with Cardiomyopathy and Poststreptococcal Glomerulonephritis. Case Rep Pediatr 2016;2016:7192359. DOI: 10.1155/2016/7192359.

6. Kasper EK, Agema WR, Hutchins GM, Deckers JW, Hare JM, Baughman KL. The causes of dilated cardiomyopathy: a clinicopathologic review of 673 consecutive patients. J Am Coll Cardiol 1994;23(3):58690. DOI: 10.1016/0735-1097(94)90740-4.

7. Marra AM, Arcopinto M, Bobbio E, Salzano A, Saccà L, Cittadini A. An unusual case of dilated cardiomyopathy associated with partial hypopituitarism. Intern Emerg Med 2012;7(Suppl 2):S85-7. DOI: 10.1007/s11739011-0649-9.

8. Filges I, Bischof-Renner A, Röthlisberger B, Potthoff C, Glanzmann R, Günthard J, et al. Panhypopituitarism presenting as life-threatening heart failure caused by an inherited microdeletion in 1q25 including LHX4. Pediatrics 2012;129(2):e529-34. DOI: 10.1542/ peds.2010-3849.

9. Frustaci A, Gentiloni N, Corsello SM, Caldarulo M, Russo MA. Reversible dilated cardiomyopathy due to growth hormone deficiency. Chest 1992;102(1):326-7.

10. Oki K, Matsuura W, Koide J, Saito Y, Ono Y, Yanagihara $\mathrm{K}$, et al. Ampulla cardiomyopathy associated with adrenal insufficiency and hypothyroidism. Int J Cardiol 2006;108(3):391-2. DOI: 10.1016/j.jijcard.2005.03.015.

11. Shah AN, Dubrey SW, Thomas D. Hypothyroid cardiomyopathy due to hypopituitarism: a diagnostic dilemma. Clin Med (Lond) 2007;7(6):639-40. DOI: 10.7861/clinmedicine.7-6-639.

12. Ng TM, Kenney JK, Munger MA. Growth hormone: a promising treatment for the failing heart? Pharmacotherapy 2000;20(9):1096-106. DOI: 10.1592/phco.20.13.1096.35035.

13. Biondi B. Mechanisms in endocrinology: Heart failure and thyroid dysfunction. Eur J Endocrinol 2012;167(5):609-18. DOI: 10.1530/EJE-12-0627. 